\title{
Causal Effect of Off-Farm Activity and Technology Adoption on Food Security in Nigeria
}

\author{
A. A. Obisesan
}

Department of Agricultural and Resource Economics, Federal University of Technology, Akure, Ondo state, Nigeria

\begin{abstract}
This study examined off-farm activity participation, technology adoption and impact on food security status of Nigerian farming households. Data were collected using structured questionnaire through a multistage sampling technique. Propensity Score Matching, descriptive statistics and Foster-Greer-Thorbecke weighted index were employed in analysis. Participation in off-farm activity has a positive and significant $(\mathrm{p}<0.05)$ influence on level of adoption. The mean per capita household food expenditure (MPCHFE) was \$30198.34 while the food insecurity line was 20132.22 per annum. The impact of improved technology adoption on food insecurity incidence of adopters with off-farm activity was higher than their counterparts without participation. This suggests that participation in off-farm activity and technology adoption have the potential to improve food security. Hence, there should be further sensitization on this technology to improve food security and policy measures should also be oriented towards the support and improvement of rural off-farm income opportunities.
\end{abstract}

\section{Keywords:}

Off-farm work, adoption, food security, rural Nigeria.

\section{Introduction}

The traditional view of rural economies as purely agricultural is obsolete. The rural areas of the sub-Saharan Africa have been thought to be synonymous with agriculture in which agricultural income activities dominate the rural economy but recently, this view has changed, there has been increasing recognition that the rural economy is not confined to agricultural sector (Csaki, Lerman, 2000). The rural households receive their income from a diverse portfolio of activities and one of the most important of these activities is that connected with the rural non-farm sector which includes different activities such as governments, commerce and services now seen as providing bulk of income to the rural households.

In Africa, about $40 \%$ of rural household incomes is generated from non-agricultural sources (Haggblade et.al., 2007), implying that off-farm activities have become a vital component of livelihood strategies among rural households. Therefore, given the importance of off-farm activity to farm households and the increasing share of off-farm income in total household income, off-farm income has recently been incorporated into the analysis of technology adoption (De Janvry and Sadoulet, 2001; Ruben and Van den Berg, 2001; Haggblade et al., 2007). According to Núñez (2005), off-farm income level of farmers has a significant impact on their decision to adopt new technologies, in that farmers with off-farm income have more financial capability to adopt new technologies.

The adoption of improved agricultural technologies is needed to improve agricultural productivity which serves as the panacea to food insecurity. In Nigeria, despite projects, programmes and policies targeted at reducing the problem of food insecurity, the country ranked $40^{\text {th }}$ on the Global Hunger Index (GHI) of 81 countries with a GHI of 15.5 indicating a serious hunger situation (IFPRI, 2011). Food insecurity is predominant in the rural areas where the main occupation is farming, $48.3 \%$ of the rural households are described food poor compared to $26.7 \%$ in the urban areas (NBS, 2012). Agricultural growth remains fundamental to food security, however, agricultural growth and development is not possible without yieldenhancing technological options because merely expanding the area under cultivation (except in few places) to meet the increasing food needs of growing populations is no longer sufficient. Thus, research and adoption of technological improvement are 
crucial to increasing agricultural productivity and food security (IFAD, 2011). Furthermore, it is expedient to conduct comprehensive impact assessment to elucidate the returns to investment in agricultural research (Kristjanson et al., 2002)

Therefore, this study examined off-farm income participation, its effect on technology adoption and the impact of improved production technology on food security status of cassava-farming households in southwest, Nigeria. It analyzed how participation in off-farm activity affects the adoption of agricultural technology by incorporating off-farm activity as an explanatory variable in the analysis of adoption of cassava improved production technology as well as the impact on food security. Specifically, this study: (1) examine the socio-economic characteristics of cassava farming households in the study area, (2) estimate the effect of off-farm activity participation on the adoption of improved production technology, (3) examine the impact of technology adoption on food security status of cassava -based farming households in the study area.

\section{Materials and methods}

The study was carried out in Southwest, Nigeria. South west is one of the six geopolitical zones in Nigeria. It falls on latitude 60 to the North and latitude 40 to the South while it is marked by longitude 40 to the West and 60 to the East. It is bounded in the North by Kogi and Kwara States, in the East by Edo and Delta States, in the South by Atlantic Ocean and in the West by Republic of Benin. The climate is equatorial with distinct wet (rainy) and dry seasons with relatively high humidity. The mean annual rainfall is 1480 $\mathrm{mm}$ with a mean monthly temperature range of $180-240^{\circ} \mathrm{C}$ during the rainy season and $300-350^{\circ} \mathrm{C}$ in the dry season. Southwest Nigeria covers approximately an area of 114,271 kilometer square that is approximately 12 percent of Nigeria's total land mass and the vegetation is typically rainforest. The total population is 27,581,992 as at 2006 (NPC, 2006). The people are predominantly farmers. The climate in the zone favours the cultivation of crops like maize, yam, cassava, millet, rice, plantain, cocoa, kola nut, coffee, palm produce, cashew etc. The zone comprises of six states namely: Ekiti, Lagos, Ogun, Ondo, Osun and Oyo states.

\section{Data collection and sampling procedure}

Primary data were collected for the purpose of this study using structured questionnaire. Some of the data include: socio-economic and demographic characteristics, cassava production, cassava production technology, and household food expenditure details.

Multistage sampling technique was employed in this study. The first stage was the random selection of Ondo and Ogun states from the six states in Southwest, Nigeria. The second stage involved the random selection of four LGAs from each state while in the third stage, three communities were randomly selected from each LGA. This resulted to 24 communities in the two states. The final stage involved a random selection of 540 respondents proportionate to the sizes of the communities. However, a total of 482 were retrieved and completely filled from the field. The survey was between August and November, 2011.

\section{Analytical techniques}

Analytical techniques employed in this study include: descriptive statistics, Tobit regression model, Propensity Score Matching (PSM) and Foster- Greer- Thorbecke (1984) model. Following (Tiamiyu et al., 2009) and adapting it to this study, technology-use ranked score was computed for each respondents based on the identified elements of the technology package (improved varieties, recommended spacing, timely maintenance, fertilizer and herbicide application) and adoption index was generated for individual farmer. Adoption index of individual farmer was calculated as follows:

$$
\begin{aligned}
& A I_{i}=\frac{T S_{i}}{T T S} \\
& A A I=\sum_{i}^{n} \frac{A I_{i}}{N}
\end{aligned}
$$

Where,

$A I_{i}=$ Adoption Index of the ith farmer

$T S_{i}=$ Technology-use Score of the ith farmer

TTS $=$ Total Technology-use Score obtainable

$A A I=$ Average Adoption Index

Total technology-use score obtainable (TTS) was obtained by allotting score to each elements of the technology package and summing them up while Technology-use score of the ith farmer $\left(T S_{i}\right)$ was obtained by summing up the scores allotted to the element of the technology package adopted by the farmer.

Tobit regression model was used to analyze 
objective 2, Following Maddala, (1997); Johnston, Dandiro, (1997) and Negash, (2007), the Tobit model for the continuous variable adoption level, can be expressed as:

$$
\begin{aligned}
A L_{i}^{*} & =\beta_{0}+\beta_{i} X_{i}+\mu_{i} \\
A L_{i} & =A L_{i}^{*} \text { if } \beta_{0}+\beta_{i} X_{i}+\mu_{i}>0 \\
& =0 \text { if } \beta_{0}+\beta_{i} X_{i}+\mu_{i} \leq 0
\end{aligned}
$$

Where,

$A L_{i}^{*}=$ the latent variable and the solution to utility maximization problem of level/ extent of adoption subjected to a set of constraints per household and conditional on being above certain limit

$A L_{i}=$ Adoption level for $\mathrm{i}^{\text {th }}$ farmer

$X_{i}=$ vector of factors affecting adoption and level of adoption

$\beta_{i}=$ vector of unknown parameters

$\mu_{i}=$ error term

\section{Selection of explanatory variables}

The explanatory variables specified as determinants of adoption level of RTEP improved production technology were selected according to Chilot et al., (1996); Asfaw et al., (1997); Nkonya et al. (1997); Mulugeta (2000); Mesfin (2005); Omonona et al.,(2006) and Negash (2007).

The variables are defined as follows:

$X_{1}=$ Age of the household head (years)

$X_{2}=$ Age square of the household head (years)

$X_{3}=$ Gender of the household head (male $=1$, 0 otherwise )

$X_{4}=$ Marital status of the household head (married $=1,0$ otherwise)

$X_{5}=$ Participation in off-farm activity (yes $=1$, 0 otherwise)

$X_{6}=$ Level of education of household head

$X_{7}=$ Years of experience of household head in cassava production (years)

$X_{8}=$ Main occupation (farming $=1,0$ otherwise)

$X_{9}=$ Household size (numbers)

$X_{10}=$ Land area cultivated (ha)

$X_{11}=$ Distance of farm to nearest market $(\mathrm{km})$

$X_{12}=$ Access to credit of the household head (yes $=1,0$ otherwise )

$X_{13}=$ Cassava yield (tonnes/ ha)

$\mathrm{X}_{14}=$ Contact with extension agents (yes $=1$, 0 otherwise)
Propensity Score Matching, one of the most commonly used quasi-experimental methods was used to address the evaluation problem (Mendola, 2007; Nkonya et al., 2007; Akinlade et al., 2011). The sample collected was matched using PSM; the aim of PSM is to find the comparison group from a sample of non-adopters that is closest to the sample of adopters so as to get the impact of the project on the beneficiaries. Though, PSM is subject to the problem of "selection on unobservables", meaning that the beneficiary and comparison groups may differ in unobservable characteristics, even though they are matched in terms of observable characteristics. However, it has been put forward that selection on unobservable is empirically less important in accounting for evaluation bias (Baker, 2000). Also in a situation where the same questionnaire is administered to both groups (so that outcomes and personal characteristics are measured in the same way for both groups) and the participants and controls are placed in a common economic environment (such as the case in this study), matching substantially reduce bias (Heckman et al., 1996).

Main steps involved in the application of statistical matching to impact evaluation are: estimating the propensity score, matching the unit using the propensity score, assessing the quality of the match and estimating the impact as well as its standard error.

Out of 482 only 387 adopters and non-adopters that had comparable propensity scores were matched. After matching, the testing of comparability of the selected groups was done and the result shows statistically insignificant difference in the explanatory variables used in the probit models between the matched groups of adopters and non-adopters.

Since the match has been deemed of good quality, this study then used the matched sample to compute the Average Treatment Effect for the Treated (ATT) to determine impact of the programme. This is defined by Rosenbaum and Rubin (1983) as follows:

$E\left(Y^{1}-Y^{0} / D=1\right)=E\left(Y^{1} / D=1\right)-E\left(Y^{0} / D=1\right)$

where, $E\left(Y^{1} / D=1\right)$ is the observed outcome of the treated, that is, the expected income earned by programme beneficiaries while participating in the programme and is the counterfactual outcome - the expected income they would have received if they had not participated in the project. The counterfactual outcome represents outcome of the non-beneficiaries since they have similar 
characteristics with beneficiaries. Standard errors were computed using bootstrapping method suggested by Lechner and Smith (2002) to generate robust standard errors in light of the fact that the matching procedure matches control households to treatment households with replacement.

Changes in food insecurity of the households were achieved by using Foster, Greer and ThorbeckeFGT (1984) model, households' expenditure on food per capita equivalent was used to determine households' food insecurity status (Omonona and Agoi, 2007).

This is defined as:

$P_{\alpha}=\frac{1}{N} \sum_{i=1}^{q} G_{i}$

Where,

$G_{i}=\left[\frac{Z-Y}{Z}\right]=$ food expenditure deficiency

$Z=$ food security line $(2 / 3$ mean per adult equivalent food expenditure)

$q=$ the number of households below the food security line,

$N=$ the total number of households in the total population,

$Y_{i}=$ the per capita equivalent food expenditure of household $i$,

$\alpha=$ the degree of food insecurity aversion;

$\alpha=0$ measures the incidence of insecurity.

$\alpha=1$ measures the depth of food insecurity.

$\alpha=2$ measure the severity of food insecurity.

STATA 10, DASP and PSM were the software package used in the analysis.

\section{Results and discussion}

\section{Distribution of respondents by socio-economic characteristics}

Table 1 shows the distribution of the respondents by socio-economic characteristics across the two types of respondents considered which are: adopters (participants) and non-adopters (non-participants). The average values of their socio-economic characteristics are within the same range due to propensity score matching (PSM) used in selecting the respondents with similar observable characteristics. Majority (74.63\%) of the adopters are males while only $25.37 \%$ are female. The average household size was 6 .
The majority of the respondents have their household sizes falling within the range of 5 to 9 people, with the average age of the respondents being 44 and 45 for adopters and non-adopters respectively. Implicit in these findings is that a large proportion of the respondents were middle aged and can therefore be regarded as active, agile and with more energy to dissipate and concentrate on productive effort. The average years of experience in cassava farming was 16 years for all respondents. The average area of land cultivated was about 1 hectare for all the respondents. Accessibility to credit facility and participation in off-farm activity was higher among adopters compared to non-adopters.

\begin{tabular}{|c|c|c|c|}
\hline Characteristics & $\begin{array}{l}\text { Categories } \\
\text { /Statistics }\end{array}$ & $\begin{array}{l}\text { Adopters } \\
\text { percentage }\end{array}$ & $\begin{array}{l}\text { Non- } \\
\text { adopters } \\
\text { percentage }\end{array}$ \\
\hline \multirow[t]{3}{*}{ Gender } & Female & 25.37 & 22.17 \\
\hline & Male & 74.63 & 77.83 \\
\hline & Total & 100 & 100 \\
\hline \multirow[t]{6}{*}{ Household size } & $0-4$ & 16.25 & 26.09 \\
\hline & $5-9$ & 77 & 68.26 \\
\hline & $>9$ & 6.75 & 5.65 \\
\hline & Total & 157 & 230 \\
\hline & Mean & 6 & 6 \\
\hline & SD & 1.9942 & 1.9576 \\
\hline \multirow[t]{7}{*}{ Age } & $\leq 30$ & 13.12 & 6.09 \\
\hline & $31-40$ & 30.25 & 26.09 \\
\hline & $41-50$ & 35.63 & 36.95 \\
\hline & $>50$ & 21 & 30.87 \\
\hline & Total & 157 & 230 \\
\hline & Mean & 44.2685 & 45.1913 \\
\hline & SD & 10.1317 & 10.7219 \\
\hline \multirow{3}{*}{$\begin{array}{l}\text { Level } \\
\text { of education }\end{array}$} & No formal & 35.67 & 26.09 \\
\hline & Primary & 51.59 & 36.52 \\
\hline & Secondary & 12.74 & 37.39 \\
\hline \multirow[t]{3}{*}{ Credit access } & Yes & 82.5 & 48.26 \\
\hline & No & 17.5 & 51.74 \\
\hline & $\leq 0.5$ & 26.75 & 22.17 \\
\hline \multirow{5}{*}{$\begin{array}{l}\text { Area of land } \\
\text { cultivated (ha) }\end{array}$} & $0.6-1.0$ & 64.33 & 50 \\
\hline & $1.1-1.5$ & 8.92 & 28.63 \\
\hline & Total & 157 & 230 \\
\hline & Mean & 0.98 & 1.01 \\
\hline & SD & 0.35 & 0.56 \\
\hline \multirow{2}{*}{$\begin{array}{l}\text { Off-farm } \\
\text { activity }\end{array}$} & Yes & 73.13 & 57.78 \\
\hline & No & 26.87 & 42.22 \\
\hline
\end{tabular}

Source: Field Survey, 2011

Table 1: Distribution of respondents by socio-economic characteristics. 
2. Participation in off-farm activity and technology adoption level

The adoption level refers to the intensity of use of improved technology by the farmers measured using their adoption scores. The adoption index generated shows to what extent the farmers have adopted the whole technology package. The level of adoption (technology-use) of cassava improved production technology by off-farm activity participation, revealed that adoption level was higher among those participating than their counterparts without participation. From Table 2, the mean adoption index of the adopters with non-farm activity participation was 0.87 while that of their non-participating counterparts was 0.58 with a mean difference of $0.29(\mathrm{p}<0.05)$. This implies that adoption level of farmers with off-farm income source was $29 \%$ higher than those without off-farm income source, significant at $5 \%$.

\begin{tabular}{lccc}
\hline $\begin{array}{l}\text { Off-farm } \\
\text { activity }\end{array}$ & Percentage & $\begin{array}{c}\text { Mean } \\
\text { adoption } \\
\text { index }\end{array}$ & $\begin{array}{c}\text { Probability } \\
\text { value }\end{array}$ \\
\hline Participation & 73.13 & 0.87 & 0.0214 \\
Non-participation & 26.87 & 0.58 & \\
\hline
\end{tabular}

Source: Source: Field Survey, 2011

Table 2: The adoption index by off-farm activity participation.

3. Effect of non-farm activity participation and other socio-economic characteristics on Adoption Level of cassava Improved Production Technology

The result of the determinants of adoption level of cassava improved production technology by farming households in the study area is shown in Table 3. The result of the Tobit regression model shows that the log likelihood is -199.69 and is significant at $1 \%$ level of significance. This indicates that the model has a good fit to the data. The result shows that out of the 14 explanatory variables included in the model, participation in off-farm activity and seven other variables were found to significantly influence level of adoption. These are gender, distance to input market, land area cultivated, years of experience in cassava production, cassava yield, access to credit and level of education. Parameter with positive signs indicates that increase in the variable increases adoption level while negative signs indicate that increase in the variable decreases adoption level.

Participation in off-farm activity has a positive and significant $(\mathrm{p}<0.05)$ influence on level of adoption. During slack periods many farmers can earn additional income by engaging in various off-farm activities. This is believed to raise their financial position to acquire new inputs. Participation in off farm activity will increase adoption level by $4.68 \%$. This concurs with Chilot et al. (1996). The gender of the farmer is significant $(p<0.01)$ and has a positive sign implying that male household heads are more likely to adopt the use of improved cassava production technology than their female counterparts. From the result, being a male household head will increase the level of adoption by $13.83 \%$. This shows that male headed households have better access to information and other resources on improved cassava production technology and are more likely to adopt new technology than female headed households. This result is in agreement with Tesfaye et al (2001); Mesfin (2005) and Omonona et al. (2006).

The coefficient of years of experience in cassava production is positive and significant $(p<0.01)$. A unit increase in years of experience in cassava production will increase the adoption level by $5.06 \%$. This is due to the fact that farmers with higher experience in cassava production appear to have full information and better knowledge hence able to evaluate the advantage of the technology. This finding is in accordance with Chilot (1994). The level of adoption of improved cassava production technology is significantly but negatively influenced by distance to the nearest input market. Market distance significantly $(p<0.01)$ reduced adoption level. This indicates that farmers nearer to the markets have more access to input. The result from this study showed that a unit decrease in market distance will increase the likelihood of adopting technology by $1.80 \%$. This concurs with Mesfin (2005) and Hailu (2008) who reported that market distance is negatively and significantly associated with adoption of crop technologies in different parts of Ethiopia.

Access to credit has positive and significant influence $(p<0.01)$ on the adoption of improved cassava production technology. From the result of this study, access to credit facilities leads to $15.82 \%$ increase in the adoption level. This is attributed to the fact that credit increases the farmers' economy to purchase improved seed, fertilizer and other inputs. This is in agreement with Mulugeta (2000) and Tesfaye et al. (2001). The level of education of the household head positively and significantly $(\mathrm{p}<0.05)$ influenced adoption level of improved production technology. Educational level will increase adoption level by $17.55 \%$. Education increases farmers' ability 
to obtain, process, and use information relevant to technology adoption. This result is in line with Chilot (1994).

The coefficient of land cultivated is positive and significant $(p<0.01)$. From the result of this study, a unit increase in land cultivated will increase adoption level of improved production technology by 0.6345 . Land is perhaps the single most important resource, as it is a base for any economic activity especially in rural and agricultural sector. It is frequently argued that farmers cultivating larger farm land are more likely to adopt an improved technology (especially modern varieties) compared with those with small farmland. This finding is consistent with Hailu (2008) that farm size exerts a positive influence on adoption of improved teff and wheat production technology in northern and western shewa zones of Ethiopia. Cassava yield has a positive and significant $(p<0.01)$ influence on adoption level. A unit increase in last season's yield will increase the adoption level of improved production technology by $14.31 \%$. This is in agreement with Omonona et al. (2006).

\begin{tabular}{|c|c|c|c|}
\hline Variables & $\begin{array}{c}\text { Marginal } \\
\text { effect }\end{array}$ & $\begin{array}{c}\text { Standard } \\
\text { error }\end{array}$ & t-value \\
\hline Gender & $0.1383 * * *$ & 0.0515 & 2.69 \\
\hline Age & -0.0223 & 0.0239 & -0.93 \\
\hline Marital status & 0.1834 & 0.1759 & 1.04 \\
\hline $\begin{array}{l}\text { Level of } \\
\text { education }\end{array}$ & $0.1755^{* *}$ & 0.0834 & 2.1 \\
\hline Main occupation & 0.0248 & 0.043 & 0.58 \\
\hline Off- farm activity & $0.0468 * *$ & 0.0229 & 2.04 \\
\hline $\begin{array}{l}\text { Distance } \\
\text { to market }\end{array}$ & $-0.0180 * * *$ & 0.0058 & -3.09 \\
\hline Land cultivated & $0.6345 * * *$ & 0.1375 & 4.61 \\
\hline $\begin{array}{l}\text { Year } \\
\text { of experience }\end{array}$ & $0.0506 * * *$ & 0.0086 & 5.88 \\
\hline Cassava yield & $0.1431 * * *$ & 0.0115 & 12.41 \\
\hline Credit access & $0.1582 * * *$ & 0.0567 & 2.79 \\
\hline Extension agent & 0.0126 & 0.0566 & 0.22 \\
\hline Household size & 0.0021 & 0.0048 & 0.08 \\
\hline Age square & 0.0003 & 0.0003 & 1.15 \\
\hline Constant & $-1.2732 * * *$ & 0.3942 & -3.23 \\
\hline Sigma & 0.5806 & 0.0319 & \\
\hline Prob $>$ chi 2 & 0 & & \\
\hline Pseudo R2 & 0.4458 & & \\
\hline Log likelihood & -199.69 & & \\
\hline
\end{tabular}

Notes: $* *,{ }^{*} * *$ are significant levels at $5 \%$ and $1 \%$ respectively Source: Field Survey, 2011

Table 3: Estimates of Tobit regression for the determinants of adoption.

\section{Food insecurity status of respondents}

From the Table 4, the estimated annual household expenditure on food consumption was 172726.53 while the mean per capita household food expenditure (MPCHFE) was 30198.34. The food insecurity line was computed for respondents using the two-thirds MPCHFE, the food insecurity line was 20132.22 per annum.

\begin{tabular}{lc}
\hline Item & Average annual expenditure \\
\hline Food & 172726.53 \\
$\begin{array}{l}\text { Mean per capital household } \\
\text { foodexpenditure (MPCHFE) }\end{array}$ & 30198.34 \\
$\begin{array}{l}\text { Food insecurity line } \\
(2 / 3 \text { MPCHFE) }\end{array}$ & 20132.22 \\
\hline
\end{tabular}

Source: Field Survey, 2011

Table 4: Annual household food expenditure profile.

\subsection{Food Insecurity Status and impact by participation in off-farm activity}

Based on the food insecurity line, $51.25 \%$ of the adopters live below the food insecurity line (food insecure). The food insecurity incidence of adopters was lower than that of the non-adopters, this reveals that improved production technology has the potential to improve food security. The food insecurity incidence was 0.5125 for adopters compared to 0.6021 for the nonadopters. Table 5 shows the food security status of respondents by participation in off-farm activity. Based on the food insecurity line, 50.65\% of adopters participating in off-farm activities were food insecure compared to $56.27 \%$ of their counterparts without participation. This reveals that food insecurity incidence among the respondents participating in off-farm activity was lower than those not participating. This might be as a result of the fact that off-farm activity increases the adoption level of improved cassava production technology in the study area.

The impact of the technology on food security status showed that the food insecurity incidence of the adopters declined by $12.42 \%$ with off-farm activity while the reduction was $5.01 \%$ with their counterparts with no participation. Furthermore, there was reduction in the food insecurity gap and severity of the adopters. The impact was significant $(\mathrm{p}<0.05)$ on the food insecurity gap of the beneficiaries participating in off-farm activity. The poverty gap of the beneficiaries declined by $38.24 \%$ for those participating in off-farm activity while the reduction was $14.68 \%$ with their counterparts without off-farm activity. 


\begin{tabular}{lcccc}
\hline $\begin{array}{l}\text { Type of Respondents/ off-farm } \\
\text { activity }\end{array}$ & Statistics & $\begin{array}{c}\text { Food Insecurity } \\
\text { Status }\end{array}$ & ATT & Impact (\%) \\
\hline ADOPTERS & F0 & 0.5065 & $\ldots \ldots \ldots \ldots$ & -12.42 \\
Participation & F1 & 0.1224 & $-0.0468^{* *}$ & -38.24 \\
& F2 & 0.0318 & -0.0141 & -44.34 \\
\hline Non participation & F0 & 0.5627 & $\ldots \ldots \ldots \ldots$ & -5.01 \\
& F1 & 0.1451 & -0.0213 & -14.68 \\
& F2 & 0.0487 & -0.0097 & -19.92 \\
\hline NON-ADOPTERS & F0 & 0.5598 & & \\
Participation & F1 & 0.1304 & & \\
& F2 & 0.0368 & & \\
\hline Non participation & F0 & 0.5869 & & \\
& F1 & 0.1477 & & \\
\hline
\end{tabular}

Note: $* *$ is significant level at $5 \%$

Source: Field Survey, 2011

Table 5: Food Insecurity Status by participation in off-farm activity.

In the same vein, the impact was higher on the food insecurity severity of the beneficiaries with off-farm activity than those with no participation. The severity reduced by $44.34 \%$ with participation while it was $19.92 \%$ with their counterparts without off-farm activity.

\section{Conclusion}

This study examined causal effect of off-farm activity and technology adoption on food security status of cassava-based farming households in Southwestern Nigeria. Empirical evidence from this study revealed a higher adoption level and impact of improved cassava technology on those participating in off-farm activity. Participation in off-farm activity, gender, land area cultivated, years of experience in cassava production, cassava yield, access to credit and level of education significantly increased technology adoption while distance to input market decreased technology adoption. The mean per capita household expenditure was $\$ 30198.34$ while the food insecurity line was $\$ 20132.22$ per annum. The food insecurity incidence of adopters was lower than that of the non-adopters. The food security status of the adopters with off-farm activity was higher than their counterparts without participation. Though, there was reduction in food insecurity indices of both participating and nonparticipating beneficiaries, implying that cassava production technology is food security improving, however, the impact was higher on the food security status of those with off-farm activity participation. Hence, Policy measures should be oriented towards the support and improvement of rural off-farm income opportunities; there should be wide dissemination of this technology to improve food security in Nigeria.

Corresponding author:

Adekemi A. Obisesan

Department of Agricultural and Resource Economics, Federal University of Technology, Akure, Ondo State, Nigeria

Phone: +2348076673676,_E-mail:kemi_triumph@yahoo.com

\section{References}

[1] Akinlade, R. J, Yusuf, S. A, Omonona, B. T. and Oyekale A. S. Poverty Alleviation Programme and Pro-poor Growth in Rural Nigeria: Case of Fadama II Project. World Rural Observations. 2011, Vol. 3, No. 1, p. 27-33. ISSN 2042-6356.

[2] Asfaw, N., Gungal, K., Mwangi, W. and Beyene S. Factors Affecting Adoption of Maize Production Technologies in Ethiopia. Ethiopian Journal of Agricultural Economics, 1997, Vol. 2, p. 52-69. ISSN 2042-6356. 
[3] Baker, J. L. Evaluating the impact of development projects on poverty. A handbook for practitioners. The International Bank for Reconstruction and Development/The World Bank, 1818 H street, N.W, Washington, D.C.20433. 2000. ISBN 0-8213-4697-0.

[4] Chilot, Y. Factors Influencing Adoption of New Wheat Technologies in the Wolmera and Addis Alem Areas of Ethiopia. An M.Sc. thesis presented to the school of graduate studies of Alemaya university of Agriculture, Ethiopia. 1994, p. 108.

[5] Chilot, Y., Shampiro, B. and Demeke, M. Factors Influencing adoption of new wheat technologies in Wolmera and Addis Alem Areas of Ethiopia.Ethiopian Journal of Agricultural economics. 1996, Vol 1, p. 63-83. ISSN 2042-6356.

[6] De Janvry, A. and Sadoulet, E. Income Strategies Among Rural Households in Mexico: The Role of Off-farm Activities. In: World Development, 2001, Vol. 29, No. 3, p. 467-480. ISSN 1873-5991, E-ISSN 0305-750X.

[7] Foster, J., Greer, J. and Thorbecke, E. A class of decomposable poverty measures. Econometrica. 1984, Vol. 52, p. 761-766. ISSN 0012-9682, E-ISSN 1468-0262.

[8] Haggblade, S., Hazell, P. and Reardon, T. Transforming the Rural Non-farm Economy. Baltimore:Johns Hopkins University Press.2007.

[9] Heckman, J., Icchimura, H. and Todd, P. Matching as an Econometric Evaluation Estimator. Review of Economic Studies, 1996, Vol. 65, p. 261-295. ISSN 0034-6527, E-ISSN 1467-937X.

[10] International Fund for Agricultural Development (IFAD), 2011. Rural Poverty Report: Enabling Poor Rural People to Overcome Poverty. Retrieved 10 th April, 2011 [Online] Available: http://www.ifad.org/rural/index.htm [Accessed 25 Sept 2014].

[11] International Food Policy Research Institute (IFPRI). Global Hunger Index. The Challenge of Hunger: Taming Price Spikes and Excessive Food Price Volatility.Washington DC. 2011.

[12] Johnston, J. and Dandiro, J. Econometrics Methods, $4^{\text {th }}$ ed., New York: McGraw Hill Companies, Inc. 1997. ISBN 0070327203.

[13] Kristjanson P., Place, F., Franzel, S. and Thornton, P. K. Assessing Research Impact on Poverty: The Importance of Farmers Perspective. Agricultural systems. 2002, Vol. 72, p. 73-92. ISSN 0308-521X, E-ISSN 1873-2267.

[14] Lechner, M. and Smith, J. Some Exogeneous Information Should Not Be Used in Evaluation, mimeo, 2002.

[15] Csaki, C. and Lerman, Z. Agrarian reform in Belarus, what has been achieved after a decade of gradualism. Quaterly Journal of International Agriculture, 2000, Vol. 39, No. 3, p. 237-260. ISSN 0049-8599.

[16] Maddala, G. S. Limited Dependent and Quantitative Variables in Econometrics. Cambridge University Press. 1997.

[17] Mendola, M. Agricultural technology adoption and poverty reduction. A propensity Score matching analysis for rural Bangladesh. Food policy, 2007, Vol. 32, p. 372-393. ISSN 0306-9192.

[18] Mesfin, A. Analysis of factors Influencing Adoption of Triticale and its Impact.The Case Farta Wereda. Msc. Thesis (Unpublished) Presented to School of Graduate Studies of Alemaya University. 2005.

[19] Mulugeta E. Determinants of Adoption of soil Conservation Practices in Central Highlands of Ethiopia. The case of three districts of Selale. M. Sc. Thesis AU. 2000.

[20] National Bureau of Statistics (NBS). Nigeria Poverty Profile. Abuja. 2012.

[21] National Population Census (NPC) National Bureau of Statistics Official Gazette (FGP 71/52007/2,500(OL24) Abuja. 2006. [Online] Available: http://www.nigerianstat.gov.ng [Accessed 15 Nov. 2014]. 
[22] Negash, R. Determinants of Adoption of Improved Haricot Bean Production in Alaba Special Woreda Southern Ethiopia. M Sc. Thesis Submitted to the Department of Rural Development and Agricultural Extension, School of Graduate Studies Haramaya University. 2007.

[23] Nkonya, E., Schroeder, T. and Norman, D. Factors affecting adoption of improved maize seed and fertilizer in North Tanzania. 1997, Indian j. Agri.econ. Vol. 48, No. 1, p.1-1 ISSN 00195014.

[24] Núñez, J. T. The Adoption of Manure Management Practices. Unpublished M.Sc. Thesis University of Missouri-Columbia. 2005.

[25] Omonona, B. T, Oni, O. A. and Uwagboe, O. A. Adoption of improved Cassava varieties and its Impact on Rural Farming Households in Edo State, Nigeria. Journal of Agriculture and Food Information, 2005, Vol 7, No. 1, p. 40-45. DOI:10.1300/J108v07n01_05

[26] Omonona, B. T. and Agoi, C. A. An Analysis of Food Security Among Nigerian Urban Households: Evidence from Lagos State, Nigeria. Journal of Central European Agriculture. 2007, Vol. 8, No. 3, p. 399-406. ISSN 1332-9049.

[27] Ruben, R. and Van den Berg, M. Nonfarm Employment and Poverty Alleviation of Rural Farm Households in Honduras. World Development. 2001, Vol. 29, Vol. 3, p. 549-60. ISSN 1873-5991, E-ISSN 0305-750X.

[28] Rosenbaum, P. R. and Rubin, D. R. The Central Role of the Propensity Score in Observational Studies for Causal Effects. 1983, Biometrika. Vol. 70, p. 41-55.ISSN 0006-3444, E-ISSN 1464-3510.

[29] Tesfaye, Z., Girma, T., Tanner, D. Verkuijl, H. Aklilu, I. and Mwangi, W. Adoption of Improved Bread Wheat Varieties and Inorganic Fertilizer by Small Scale Farmers in Yelma Dansa and Farta Districts of Northern Ethiopia. Mexico, D.F. Ethiopian Agricultural Research Organization (EARO) and International Maize and Wheat Improvement Center (CIMMYT). 2001.

[30] Tiamiyu, S. A., Akintola, J. O. and Rahji, M. A. Y. Technology Adoption and Production Difference among Growers of New Rice for Africa in Savanna Zone of Nigeria. 2009. Tropicultura, Vol. 27, No. 4, p. 193-197. ISSN ISSN 0771-3312, E-ISSN 2295-8010. 